\title{
Pseudo-nitzschia sp. cf. pseudodelicatissima - a confirmed producer of domoic acid from the northern Gulf of Mexico
}

\author{
Youlian Pan ${ }^{1,2, *}$, Michael L. Parsons ${ }^{3, * *}$, Mark Busman ${ }^{1}$, Peter D. R. Moeller ${ }^{1}$, \\ Quay Dortch $^{3}$, Christine L. Powell ${ }^{3}$, Gregory J. Doucette ${ }^{1,2, * * *}$ \\ ${ }^{1}$ Marine Biotoxins Program, Center for Coastal Environmental Health and Biomolecular Research, NOAA National Ocean \\ Service, 219 Fort Johnson Road, Charleston, South Carolina 29412, USA \\ ${ }^{2}$ Marine Biomedical and Environmental Sciences, Medical University of South Carolina, 221 Fort Johnson Road, Charleston, \\ South Carolina 29412, USA \\ ${ }^{3}$ Louisiana Universities Marine Consortium, 8124 Highway 56, Chauvin, Louisiana 70344, USA
}

\begin{abstract}
Domoic acid (DA), a potent neurotoxin, is synthesized by certain members of the ubiquitous marine diatom genus Pseudo-nitzschia. We recently detected elevated concentrations of DA in phytoplankton field samples from the northern Gulf of Mexico. In searching for a possible source of the toxin, we used a receptor-binding assay to detect DA activity in cultures of $P$. sp. cf. pseudodelicatissima (Hasle) isolated from this region and confirmed its presence in 2 of 7 clones using liquid chromatography coupled with tandem mass-spectrometric detection (LC-MS/MS). Unlike other toxic Pseudo-nitzschia species examined previously (e.g., P. multiseries, P. australis), cellular levels and net production of DA in these clones were highest in the early exponential phase, while the population growth rate was high and cell concentration was low. There was a negative correlation between cellular DA and cell concentration. The maximum cellular DA activity in cultures was $36 \mathrm{fg}$ DA equiv. cell $^{-1}$. No net toxin production was evident in the stationary phase, yet extracellular DA levels increased markedly during this period to as much as $88 \%$ of the total DA in the cultures. Interestingly, these 2 toxic clones were able to enlarge their cell size after the apical axes declined to 15 to $25 \mu \mathrm{m}$, and these larger cells had considerably higher levels of DA than the original small cells. This study unequivocally establishes $P$. sp. cf. pseudodelicatissima as a source of DA in the northern Gulf of Mexico. Moreover, our work suggests that rapidly growing, rather than nutrient-limited, populations of this diatom should yield maximum net DA production rates and DA cell quotas. Thus, the presence of $P$. sp. cf. pseudodelicatissima cells, even at the low levels of early, rapidly growing bloom stages, can potentially lead to toxic events.
\end{abstract}

KEY WORDS: Pseudo-nitzschia $\cdot$ Domoic acid $\cdot$ Harmful algal blooms $\cdot$ Receptor-binding assay $\cdot$ Gulf of Mexico

Present addresses:

${ }^{*}$ Institute for Marine Biosciences, National Research Council, 1411 Oxford St. Halifax, Nova Scotia B3H 3Z1, Canada

${ }^{* *}$ Natural Sciences Division, Marine Science Department,

University of Hawaii-Hilo, 200 W. Kawili Street, Hilo, Hawaii 96720, USA

${ }^{* * *}$ Corresponding author. E-mail: greg.doucette@noaa.gov

\section{INTRODUCTION}

Species of Pseudo-nitzschia have been associated with production of a neurotoxin, domoic acid (DA) (e.g. Subba Rao et al. 1988, Bates et al. 1989, Garrison et al. 1992, Lundholm et al. 1994, Rhodes et al. 1998), which caused human amnesic shellfish poisoning in the 
Canadian Atlantic region (Todd 1993), as well as mass mortalities of sea birds (Work et al. 1993, Sierra Beltran et al. 1997) and sea lions (Scholin et al. 2000) along the Pacific coasts of California and Mexico. Pseudonitzschia spp. have been documented from the Arctic to the Antarctic, ranging from coastal to oceanic waters. The ubiquitous distribution of Pseudo-nitzschia spp. and their association with DA production has brought worldwide attention to this phytoplankton group (Bates et al. 1998 and references therein).

Seven species of Pseudo-nitzschia have been documented to produce DA, but time-course studies of DA production have been conducted for only 3 species (i.e., $P$. multiseries, $P$. australis, $P$. seriata). This body of work includes only 1 report for $P$. australis (Garrison et al. 1992) and 1 for P. seriata (Lundholm et al. 1994), with the majority of such investigations focusing on $P$. multiseries, the first diatom reported to produce DA. In $P$. multiseries, DA production has been detected only in the late exponential and stationary phases of batch culture, when cell division either declines or ceases (Bates 1998, Pan et al. 1998 and references therein). The toxin production rate is greatly enhanced when cell division terminates during the stationary phase (Pan et al. 1996a), and there is an inverse correlation between DA production and growth rate (Pan et al. 1996b). This enhanced DA production is believed to be attributable to nutritional stresses, such as phosphate or silicate limitation (Pan et al. 1998 and references therein). In P. australis, Garrison et al. (1992) observed initiation of DA production in the exponential phase, but could not rule out the possibility that due to a high initial inoculum, cells were already experiencing nutritional stress at this time.

Elevated concentrations of Pseudo-nitzschia spp. $\left(>10^{7}\right.$ cells $\mathrm{l}^{-1}$ ) have been found in northern Gulf of Mexico coastal waters off Louisiana (Dortch et al. 1997), while lower concentrations tend to occur along the Texas coast (G. A. Fryxell pers. comm., Q. Dortch

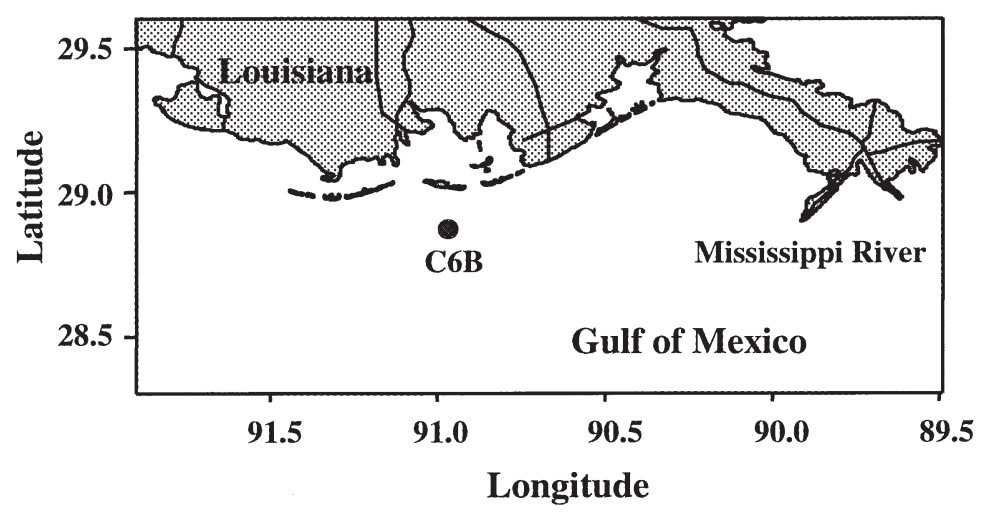

Fig. 1. Map of Louisiana coast showing the location of Stn C6B $\left(28.8597^{\circ} \mathrm{N}, 90.4673^{\circ} \mathrm{W}\right)$ where the Pseudo-nitzschia sp. cf. pseudodelicatissima clones were isolated unpubl.). Domoic acid has been detected in cultures of P. multiseries isolated from the Texas coast (Reap 1991, Dickey et al. 1992). More recently, high concentrations of DA were found in net tow samples from the Louisiana coast containing large numbers of Pseudonitzschia, comprised of over $90 \%$ P. sp. cf. pseudodelicatissima (Parsons et al. 1999). P. sp. cf. pseudodelicatissima cells from Louisiana coastal waters were isolated into culture, and this paper reports the detection and confirmation of DA production in cultures of this diatom, as well as the physiology of toxin production.

\section{MATERIALS AND METHODS}

Cultures. Seawater samples were collected on April 14, 1998 from Stn C6B (28.8597 ${ }^{\circ}$, 90.4673 W: Fig. 1) in the northern Gulf of Mexico. Single cells or single chains of Pseudo-nitzschia sp. cf. pseudodelicatissima were isolated from these samples and established in individual laboratory cultures. These cultures were maintained in $50 \mathrm{ml}$ glass tubes containing $25 \mathrm{ml}$ of $\mathrm{f} / 2$ medium (Guillard \& Ryther 1962) at $20 \pm 1^{\circ} \mathrm{C}$, and under $100 \mu \mathrm{mol}$ photons $\mathrm{m}^{-2} \mathrm{~s}^{-1}$ cool-white fluorescent light provided on a 16:8 light:dark cycle. Salinity of the culture medium was 30 psu.

Detection of domoic acid. Seven clones of Pseudonitzschia sp. cf. pseudodelicatissima were tested for DA presence. For initial screening, cultures (10 to $20 \mathrm{ml}$ ) were harvested in early stationary phase (Day 15) on GF/F filters (Whatman, Fairfield, NJ), extracted in $10 \%$ aqueous methanol, and tested for DA activity using a receptor-binding assay (van Dolah et al. 1997). The detection limit of this method is ca 6 nM DA equivalents $\left(1.9 \mu \mathrm{g}\right.$ DA equiv. $\mathrm{l}^{-1}$ ). The DA receptor assay data are expressed as DA equivalents, based on a certified reference standard (DACS-1C, Institute for Marine Biosciences, NRC, Halifax, Nova Scotia, Canada). In a previous study (van Dolah et al. 1997), assay values agreed closely with quantification of DA in Pseudo-nitzschia multiseries cultures by the HPLC-FMOC method. The 2 clones testing positive in the receptor assay were scaledup to $250 \mathrm{ml}$ in $500 \mathrm{ml}$ Erlenmeyer flasks and harvested during early stationary phase (6 to $10 \mathrm{~d}$ ). Parallel samples were taken for direct microscopic cell counts, DA receptor assays, and confirmation of toxin presence by liquid chromatography coupled with tandem mass-spectrometric detection (LC-MS/MS: see Scholin et al. 2000). For LC-MS/MS analyses, cell extracts were passed over a C18 column (Vydac 201TP, The Separations Group, Inc., Hesperia, CA) employing a mobile phase gradient of 1 to $95 \%$ meth- 
anol in $0.1 \%$ triflouroacetic acid. A PE SCIEX API-III triple quadrupole mass-spectrometer (SCIEX Instruments, Thornhill, Ontario, Canada) was used in positive ion mode with compressed air as the nebulization gas, and confirmation of DA was based on the MS/MS fragmentation pattern for this toxin given by Quilliam (1996).

Dissolved domoic acid in the culture medium (i.e., passing through a GF/F filter) was collected on a Bakerbond PolarPlus C-18 column (2 g packing, J. T. Baker, Phillipsburg, New Jersey, USA) by passing $12 \mathrm{ml}$ of culture filtrate over the column at a flow rate of $<1 \mathrm{ml} \mathrm{min}{ }^{-1}$. Domoic acid retained on the column was eluted using acidified methanol (containing 1\% acetic acid). The recovery rate was ca $80 \%$. This novel approach to extracting dissolved DA from culture medium is undergoing further modifications that are ultimately expected to enhance the current recovery rate (Pan et al. unpubl. data). Domoic acid activity in the culture filtrate was measured by receptor assay.

Toxin production. Once DA production was confirmed in the $250 \mathrm{ml}$ cultures, cellular toxin levels (i.e., retained on GF/F) of the 2 positive clones were examined over the course of a batch culture growth cycle. Five liters of $\sim 30$ psu seawater were autoclaved in a 101 polycarbonate carboy and then cooled to room temperature before amendment with $f / 2$ medium enrichments. After mixing, aliquots of 1.61 were dispensed into 3 autoclaved $2.8 \mathrm{l}$ glass Fernbach flasks. Exponentially growing cells were inoculated into each flask at an initial concentration of $10^{4}$ cells ml- ${ }^{-1}$. Samples for cell concentration $(5 \mathrm{ml})$ and DA activity (100 ml, cellular and dissolved) were collected at various times during the growth cycle. Cell concentrations were determined by direct microscopic counting and DA activity was measured as described above. Net DA production rates were calculated by:

$$
\text { DA prod (equiv. cell } \left.{ }^{-1} \mathrm{~d}^{-1}\right)=\frac{\mathrm{DA}_{2}-\mathrm{DA}_{1}}{0.5\left(N_{1}+N_{2}\right) /\left(t_{2}-t_{1}\right)}
$$

where DA is domoic acid concentration (fg DA equiv. $1^{-1}$, cellular plus dissolved DA), $N$ is cell concentration (cells $\mathrm{l}^{-1}$ ), and $t$ is time (d).

Potential effect of bacteria on DA degradation. Bacteria-containing filtrate was collected from early $(9 \mathrm{~d}$ old, data not shown) or late stationary phase ( $42 \mathrm{~d}$ old) cultures of Pseudo-nitzschia sp. cf. pseudodelicatissima. Diatom cells were removed by gravity filtration through polycarbonate filters ( 3 or $5 \mu \mathrm{m}$ pore diam.; Osmonics, Livermore, CA), and the filtrate was determined to be cell-free by direct microscopic examination. A DA reference standard (25 $\mathrm{\mu g} \mathrm{l}^{-1}$ final concentration; DACS-1C) was then introduced to the filtrate. The same DA reference standard was added to autoclaved, bacteria-free $f / 2$ medium that was treated in the same way and served as a control. The filtrate and control ( $4.5 \mathrm{ml}$ aliquots) were then dispensed into 3 test tubes, which were incubated for $5 \mathrm{~d}$ in the dark at $20^{\circ} \mathrm{C}$. Samples $(0.5 \mathrm{ml})$ were collected daily (Days 0 through 5) and passed through a syringe filter $(0.2 \mu \mathrm{m}$ pore diam.), and kept frozen until analysis by receptor assay. Since the DA standard was dissolved in methanol (final concentration $<0.1 \%$ ), which can kill bacteria at a high concentration, bacterial viability following the DA addition was confirmed by plating 1 drop of culture on enriched seawater-based agar plates (both SWC and DBG/5 media, Doucette et al. 1999). Thousands of bacterial colonies grew up on the plates.

For quantification of total bacterial numbers, $2 \mathrm{ml}$ aliquots of culture (or its dilution using freshly made, autoclaved medium) were combined with the fluorescent DNA stain SYTOX $(0.01 \%$ final concentration; Molecular Probes, Eugene, OR). After staining for 20 to 30 min, samples were filtered onto black polycarbonate filters $(0.22 \mu \mathrm{m}$ pore diam.). The filters were then mounted between microscope slides using immersion oil, and bacteria were enumerated with an epifluorescence microscope. For approximate quantification of viable bacteria, the plating method described above was used.

Morphology, electron microscopy. Bright-field digital light micrographs of cells for frustule measurements were taken using a Zeiss Axiovert S100 microscope (Carl Zeiss Inc., Thornwood, NY) and a Spot 2 CCD camera (Diagnostic Instruments Inc., Sterling Heights, MS). Frustule morphology was examined by both scanning (SEM) and transmission (TEM) electron microscopy. For SEM analysis, material was fixed with freshly prepared paraformaldehyde $(1 \%)$ for $1 \mathrm{~h}$, and frustules were then acid-cleaned successively in concentrated $\mathrm{HCl}_{1} \mathrm{HNO}_{3}$, and $\mathrm{H}_{2} \mathrm{SO}_{4}$ at or near $100^{\circ} \mathrm{C}$ for $1 \mathrm{~h}$ (modified from Cupp 1943). Cleaned frustules were delivered to the Institute for Marine Biosciences, NRC (Halifax, Nova Scotia, Canada) for SEM examination (JEOL 30 CX, Jeol Ltd., Tokyo, Japan). For TEM analysis, material was fixed with freshly prepared paraformaldehyde $(1 \%)$, and frustules were processed according to methods outlined in Parsons et al. (1999). Briefly, samples were acid-cleaned in boiling $\mathrm{HNO}_{3}$ for $40 \mathrm{~min}$, followed by 6 rinses with distilled water. Rinsed samples were resuspended in $1 \mathrm{ml}$ of distilled water and a $0.1 \mathrm{ml}$ subsample was transferred to a 200-mesh copper grid for TEM examination at the University of Hawaii at Hilo (Zeiss EM109, Carl Zeiss Inc.). Dr G. A. Fryxell (University of Texas, Austin, TX) was consulted for the tentative identification of Pseudo-nitzschia sp. cf. pseudodelicatissima clones used in this study, and details of their morphology and taxonomy will be reported in a subsequent paper. 

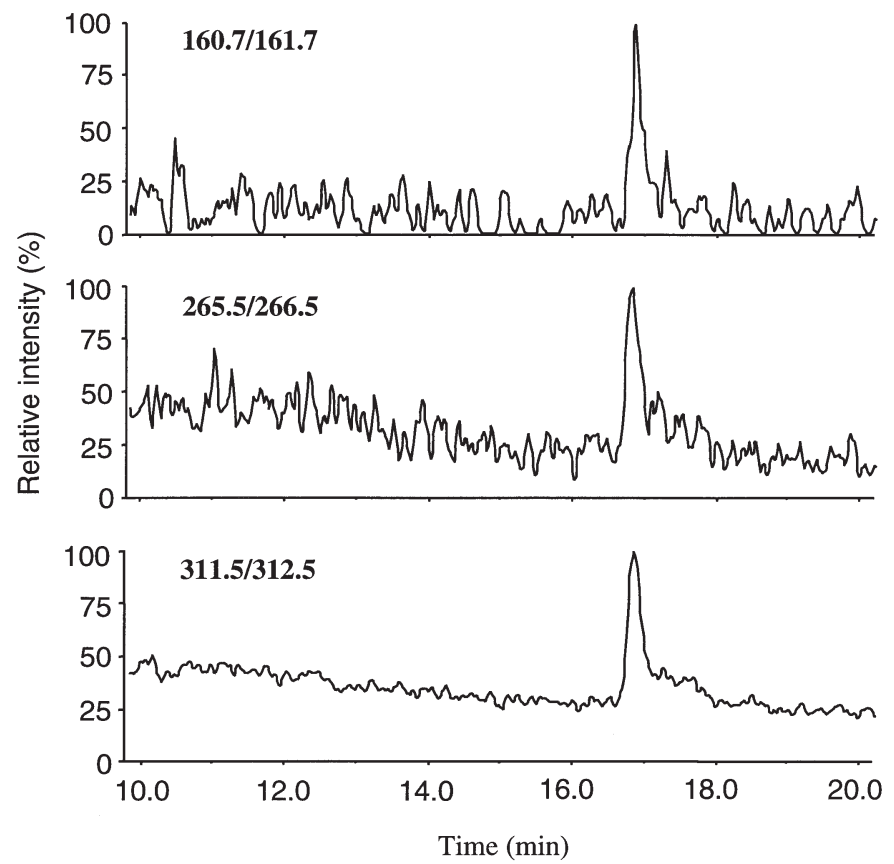

Fig. 2. Pseudo-nitzschia sp. cf. pseudodelicatissima. Domoic acid extracted with $10 \%$ aqueous $\mathrm{MeOH}$ or $5 \% \mathrm{NH}_{4} \mathrm{OH}$ from diatom cells and confirmed using tandem mass spectrometry, following HPLC separation (LC-MS/MS). Bottom chromatogram shows the intact DA pseudo-molecular ion, upper 2 chromatograms demonstrate the presence of 2 principal daughter ion fragments according to Quilliam (1996). Numbers in upper left corner of each panel: selected ion monitoring (SIM) range (e.g., for the $312 \mathrm{~m} / \mathrm{z}$ DA pseudo-molecular ion the SIM range is 311.5 to 312.5 )

\section{RESULTS}

Of the 7 Pseudo-nitzschia sp. cf. pseudodelicatissima clones tested, two (9D3C2-1, 9D2C1-1) were positive in the DA receptor-binding assay, and DA presence was confirmed in both cases by LC-MS/MS (Fig. 2). The DA pseudo-molecular ion $(\mathrm{m} / \mathrm{z}=312)$ was observed at a $17 \mathrm{~min}$ elution time. Concurrently, the 2 primary diagnostic fragment ions $(\mathrm{m} / \mathrm{z}=266$ and 161) were also detected at the same elution time, verifying the identity of the DA molecule (see Quilliam 1996).

The average specific growth rates for early exponential phase cultures of Clones 9D3C2-1 and 9D2C11 (Fig. 3A) were estimated at 0.63 and $0.51 \mathrm{~d}^{-1}$, respectively. The maximal net toxin production rate for 9D3C2-1, calculated during early exponential phase (Day 1), was 38.5 fg DA equiv. cell ${ }^{-1} \mathrm{~d}^{-1}$ (Fig. 3E). Subsequently, when population growth slowed in late exponential phase and finally stopped in early stationary phase, toxin accumulation in the cultures exhibited a pattern similar to that of growth (Fig. 3B). In fact, as the cultures entered the stationary phase, DA cell quotas decreased (Fig. 3D), and there was no perceptible net toxin production (Fig. 3E). Thus, for both clones, there was an overall negative correlation between cellular DA and cell concentration (Fig. 4) as well as growth rate.

Declining intracellular toxin levels during the stationary phase suggested that DA was being released into the culture medium. However, initial attempts to directly measure DA in the medium were unsuccessful, as toxin levels were below the receptor assay's detection limit. We therefore developed a solid phase extraction protocol to concentrate toxin directly from the seawater medium (see 'Materials and methods').

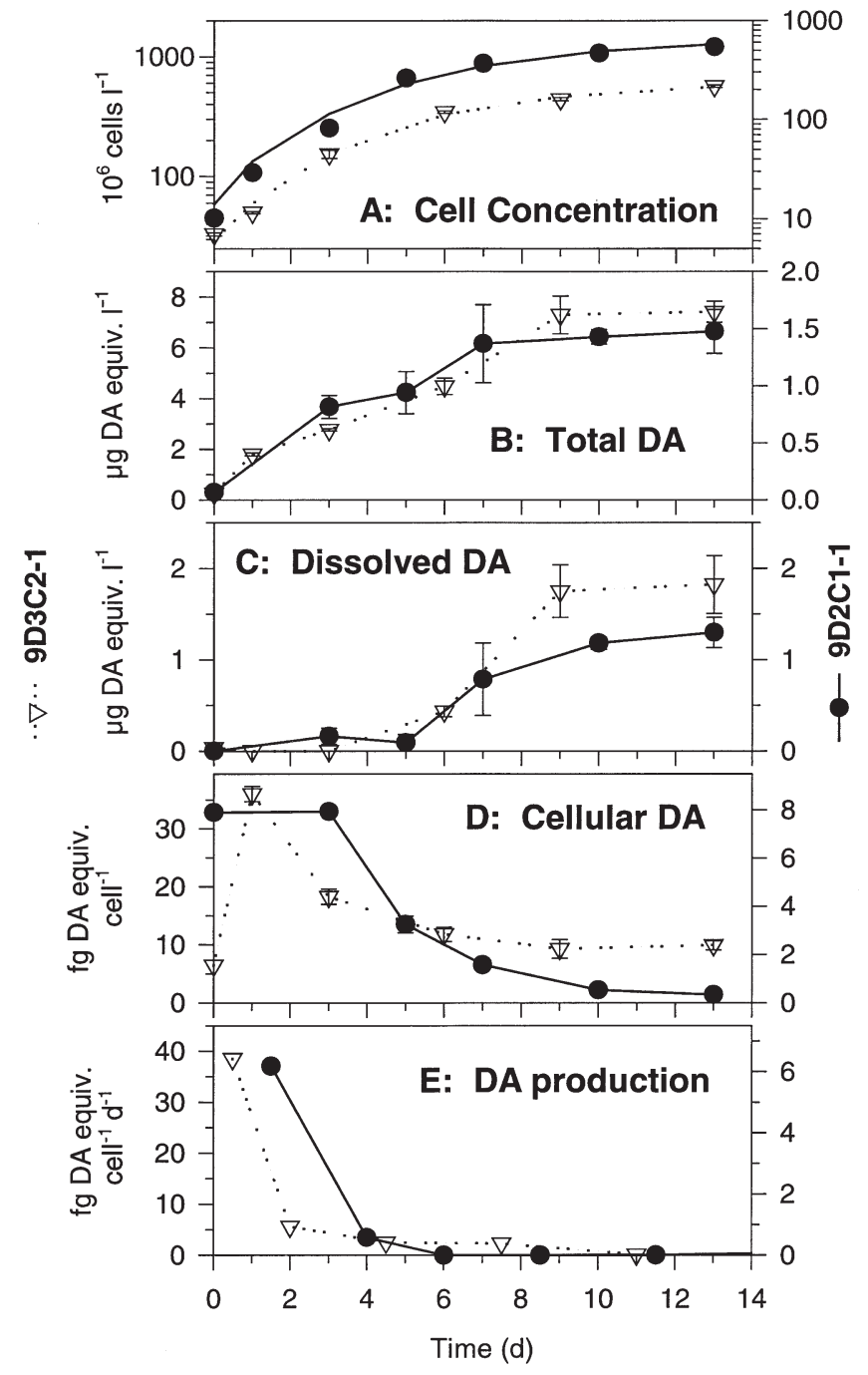

Fig. 3. Pseudo-nitzschia sp. cf. pseudodelicatissima. Changes in (A) cell concentration, (B) total, (C) dissolved and (D) cellular domoic acid (DA) levels, and (E) net DA production rate over a growth cycle of 2 clones. Both clones showed the same pattern of variation. Note: because of the difference in toxin levels and net toxin production rate between the 2 clones, different vertical axes are used: Left, 9D3C2-1; right, 9D2C1-1. Error bars $=1 \mathrm{SE}$. Curves (A) are fitted to Gompertz growth model (Zwietering et al. 1990) 

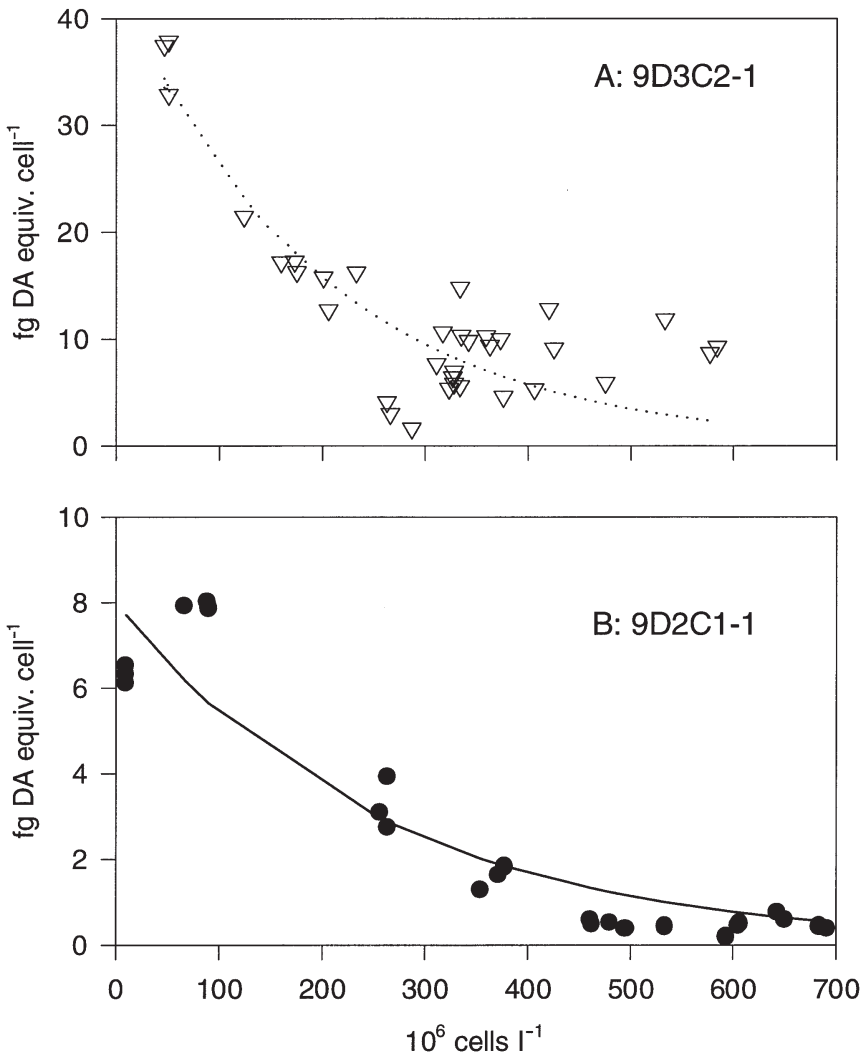

Fig. 4. Pseudo-nitzschia sp. cf. pseudodelicatissima. Negative relationship between cellular DA and cell concentration. Curves are fitted to an exponential function

Up to $88 \%$ of the total DA was found in the growth medium during the stationary phase (Fig. 3C).

We also investigated the possibility that the relatively constant total DA levels in stationary phase cultures (Fig. 3B) might be attributable to breakdown of the toxin upon its release into the medium, and examined the potential for bacterial DA degradation. An increase in bacterial abundance during the stationary phase was noted, with the majority of bacteria being attached to the surface of Pseudo-nitzschia sp. cf. pseudodelicatissima cells. The attachment of bacteria to $P$. sp. cf. pseudodelicatissima appeared to coincide with lysis of the diatom cells and thus could have promoted toxin leakage. Nonetheless, there were millions of viable bacteria per milliliter in the culture medium, yet they were unable to degrade the DA standard added to the filtrate from which the diatom cells had been removed (Fig. 5).

We observed marked changes in the cell size of both Pseudo-nitzschia sp. cf. pseudodelicatissima clones. Over a period of 4 to $5 \mathrm{mo}$, the apical axis declined from $50-60 \mu \mathrm{m}$ when they were first established in culture, to $25-30 \mu \mathrm{m}$, when the growth rates had noticeably slowed. One culture of 9D3C2-1 was subcultured every 3 to $5 \mathrm{~d}$ for 2 mo without entering the stationary phase. The culture then stopped growing, at which time we observed that the interstrial pattern on the frustule was distorted in ca 20 to $30 \%$ of the cells (Fig. 6A). This phenomenon was not observed when population growth was obvious. A significant reduction in cell size was also noticed in other toxic cultures of both clones, which were subcultured 1 to $2 \mathrm{wk}$ after entering the stationary phase. No distortion of the interstrial pattern occurred in these cultures. The rate of reduction in the apical axis was not as drastic as that in the cultures maintained in exponential phase for 2 mo. After the apical axis length reached 15 to $25 \mu \mathrm{m}$, the cells of both toxic clones were able to re-establish their original dimension without mating with another clonal culture. We were unable to identify any putative gametes or auxospores in these cultures. The elongated cells had apical axes of 74 to $80 \mu \mathrm{m}$ in Clone 9D3C2-1 and 100 to $110 \mu \mathrm{m}$ in Clone 9D2C1-1, while retaining the same overall frustule structure and the ability to produce DA (Table 1). Interestingly, the DA content of these elongated cells was an order of magnitude greater than for the original smaller cells (Table 1). When viewed by SEM, the elongated cells from both cultures exhibited an atypical poroid structure of the interstriae in which cells appeared to have double rows of valve face poroids (Fig. 6B). However, a

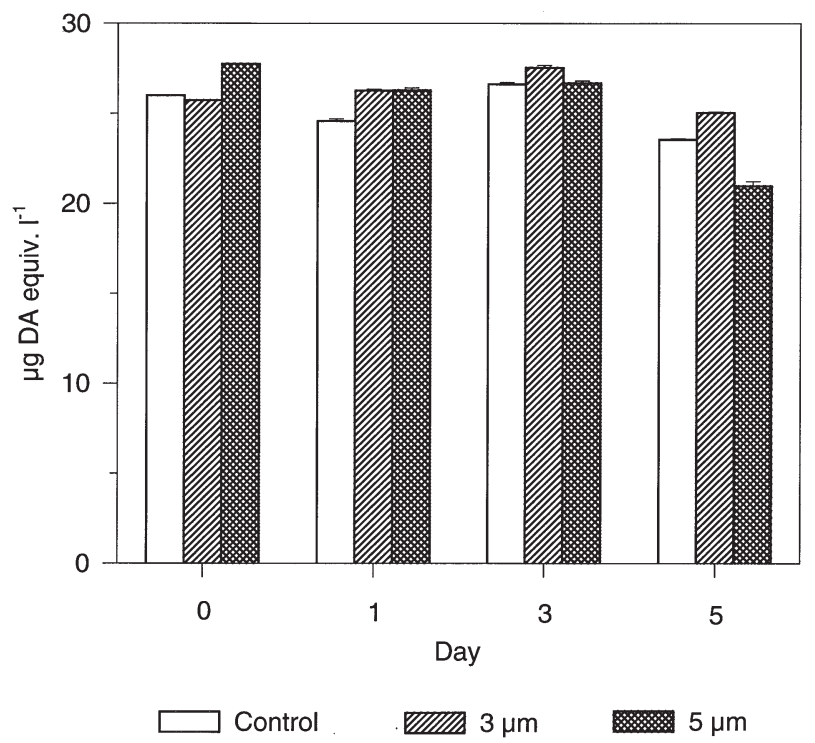

Fig. 5. Pseudo-nitzschia sp. cf. pseudodelicatissima. Potential for domoic acid degradation in bacteria-containing medium from diatom culture (42 d). Bacteria-containing culture medium was collected following removal of algal cells by filtration through 3.0 or $5.0 \mu \mathrm{m}$ polycarbonate filters. Domoic acid reference standard was introduced to the culture filtrate and incubated for $5 \mathrm{~d}$. Key indicates pore sizes of filters used. See 'Materials and methods' for more details 
more detailed examination by TEM revealed that the 'double-poroid' appearance was due to the presence of 2 to 4 large hymenate sectors in the velum of each poroid (Fig. 6C).

\section{DISCUSSION}

The present study is the first to provide mass spectrometric confirmation of DA synthesis by cultured Pseudo-nitzschia sp. cf. pseudodelicatissima originating from US waters. The first detailed examination of $P$. sp. cf. pseudodelicatissima toxin production physiology is also reported herein. Domoic acid has been documented previously in P. pseudodelicatissima from the Bay of Fundy, Canada (Martin et al. 1990), and more recently from New Zealand (Rhodes et al. 1998), the Baltic Sea (Lundholm et al. 1997), the northern Gulf of Mexico (Parsons et al. 1999), and coastal waters of Washington, USA (Adams et al. 2000). However, many other clones of this same species isolated from other parts of the world have been found to be non-toxic (see Bates et al. 1998).

The term 'toxin production' is often (mis)used in the literature to refer to toxin level (e.g. cellular toxin) rather than the net rate of toxin accumulation, essentially the toxin biosynthesis minus loss terms, such as bio-degradation and/or transformations (Pan et al. 1998). Toxin production can be zero when toxin levels (in the cells and medium) are very high, and vice versa. Here we distinguished rates of toxin production from toxin levels.

In our Pseudo-nitzschia sp. cf. pseudodelicatissima batch cultures, net toxin production was observed only during exponential phase, and DA cell quotas were negatively correlated with cell concentration. A similar pattern was also reported once previously for $P$. australis cultures isolated from Monterey Bay, California (Garrison et al. 1992), yet may have reflected the early onset of nutritional stress due to a heavy starting inoculum. The work of Pan et al. (1996b) revealed that $P$. multiseries produced DA during late exponential phase while population growth rates declined; however, net toxin production rates remained an order of magnitude lower than in the stationary phase, and cellular DA levels were unrelated to cell concentration. As these $P$. multiseries cultures entered the stationary phase, DA production increased and attained maximal levels coincident with more severe nutrient limitation (Pan et al. 1996a). The pattern of toxin production in $P$. seriata (Lundholm et al. 1994) appears to be similar to that of $P$. multiseries. Such was not the case for P. sp. cf. pseudodelicatissima in the present study, with maximal net DA production rates occurring over the first few days of culture growth when cell concentrations were lowest (Fig. 3A,E). The cellular toxin content of Clone 9D3C2-1 increased from 6.4 to $36 \mathrm{fg}$ DA equiv. cell ${ }^{-1}$ during the first day, and the corresponding toxin production rate was calculated to be $38.5 \mathrm{fg}$ DA equiv. cell $^{-1} \mathrm{~d}^{-1}$. Similarly, the DA production rate for Clone

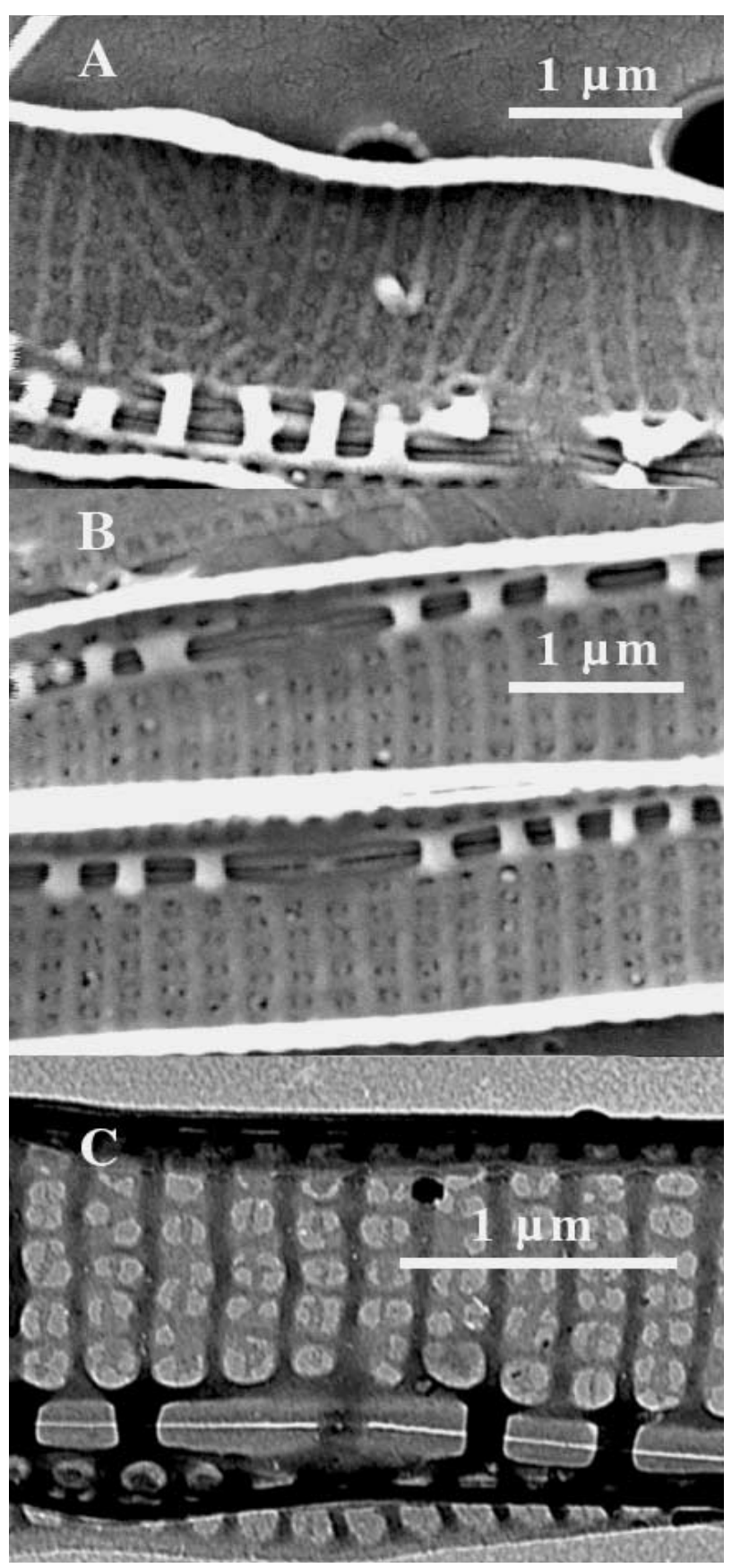

Fig. 6. Pseudo-nitzschia sp. cf. pseudodelicatissima. (A,B) Scanning and (C) transmission electron micrographs of diatom frustules. (A) distorted interstrial structure of the short cells of Clone 9D3C2-1; (B) elongated cells of Clone 9D2C1-1; (C) elongated cells of Clone 9D2C1-1 showing atypical velum structure. Note central interspace visible on all frustules 
Table 1. Pseudo-nitzschia sp. cf. pseudodelicatissima. Cell morphology and cellular domoic acid content of 2 toxigenic clones from the northern Gulf of Mexico

\begin{tabular}{|lcccc|}
\hline & \multicolumn{2}{c}{ Clone 9D2C1-1 } & \multicolumn{2}{c|}{ Clone 9D3C2-1 } \\
& $\begin{array}{c}\text { Long } \\
\text { cells }\end{array}$ & $\begin{array}{c}\text { Original } \\
\text { short cells }\end{array}$ & $\begin{array}{c}\text { Long } \\
\text { cells }\end{array}$ & $\begin{array}{c}\text { Original } \\
\text { short cells }\end{array}$ \\
\hline Apical axis $(\mu \mathrm{m})$ & $>100$ & $20-25$ & $74-80$ & $25-30$ \\
Growth rate $\left(\mathrm{d}^{-1}\right)$ & 0.62 & $<0.2$ & 0.52 & 0.3 \\
$\begin{array}{l}\text { Stationary phase cellular DA } \\
\left(\text { fg DA equiv. cell }{ }^{-1} \text { ) }\right.\end{array}$ & 12.8 & 0.3 & $36.1 \pm 1.3$ & $2.7 \pm 0.3$ \\
& & & & \\
\hline
\end{tabular}

9D2C1-1 was highest during the first $3 \mathrm{~d}$ of culture, even though toxin cell quotas remained unchanged and at maximal levels over this interval (Fig. 3D).

Our finding of the highest toxin production rates during exponential growth suggests that the presence of Pseudo-nitzschia sp. cf. pseudodelicatissima, even at the low cell concentrations of early, rapidly growing bloom stages, can potentially lead to toxic events. Even in the case of short-lived blooms, accumulation of cell biomass may parallel toxin production. When heavy feeding by zooplankton and shellfish coincides with a rapid division of highly toxic cells, DA may be accumulated at an elevated rate in these consumers. Such a scenario, whereby even a brief but strong 'pulse' of toxin enters the food web, has been implicated previously in the trophic transfer of DA linked with marine faunal mortality events (e.g. Scholin et al. 2000) and thus has the potential to occur in Louisiana coastal waters.

It is premature to speculate as to the potential mechanism responsible for the differences in DA production between Pseudo-nitzschia sp. cf. pseudodelicatissima and $P$. australis on the one hand, and $P$. multiseries and $P$. seriata on the other. Production of DA during the early exponential phase of the former species suggests that the mechanism of toxin production may differ among members of even the same genus. Generalization of Pseudo-nitzschia spp. toxin production characteristics can be misleading, and may result in a failure to detect DA in potentially toxic clones. Based on our data, we recommend that DA production be examined over the entire growth cycle of Pseudo-nitzschia spp. Some Pseudo-nitzschia species or strains that have not yet been established as toxic may, in fact, be toxigenic. With advances in technology and increases in sensitivity of detection methods, more toxic species are likely to be discovered.

As has been reported for Pseudo-nitzschia multiseries (Bates et al. 1991), substantial quantities of DA were released into the medium of $P$. sp. cf. pseudodelicatissima cultures, especially during the stationary phase (Fig. 3C). However, no increase in total DA concentrations was observed. This raised the concern that toxin might also be produced in the stationary phase, but released and degraded in the medium. We therefore investigated the potential for a dynamic balance between DA production by $P$. sp. cf. pseudodelicatissima and toxin degradation by bacteria and other effects. Nevertheless, we were unable to detect any obvious bacterial effect on DA degradation during our experiment (Fig. 5). We performed the experiment using filtrates of both early and late stationary phase cultures, and the results were consistent.

Most Pseudo-nitzschia clones are unable to survive more than several years following isolation. It is a generally accepted hypothesis that diatom cells lose their viability when they reach a critical point, following a progressive reduction in size through subsequent cell division cycles (Mann et al. 1999). Cells of P. multiseries become lobate in some older clones (e.g. Subba Rao \& Wolgeschaffen 1990). We also observed lobate cells in P. sp. cf. pseudodelicatissima cultures when the cells' apical axes were $30 \mu \mathrm{m}$ or shorter; some of these cells were able to divide, while others were not. After maintaining cultures in active growth for about 2 mo by transferring to fresh medium every 3 to $5 \mathrm{~d}$, we noticed a drastic reduction in the cells' apical axes ( 7 to $10 \mu \mathrm{m} \mathrm{mo}{ }^{-1}$ ) down to about 20 to $25 \mu \mathrm{m}$. Finally, the cells were unable to divide and barely survived. Interestingly, the interstrial pattern on many frustules in these cultures was distorted (e.g. Fig. 6A). These distorted interstriae could be a characteristic of cells incapable of further division and merit further investigation.

When subcultured less frequently and maintained in stationary phase for a period of 1 to $2 \mathrm{wk}$ before the next transfer to fresh $f / 2$ medium, the rate of reduction in apical axis length declined (less than $5 \mu \mathrm{m} \mathrm{mo}{ }^{-1}$ ). Cells from both Pseudo-nitzschia sp. cf. pseudodelicatissima clones that were transferred less frequently (once every 3 to $4 \mathrm{wk}$ ), were capable of re-establishing their original size due to an as yet unknown mechanism. Davidovich \& Bates (1998) recently reported dioecious sexual reproduction in 2 species of Pseudonitzschia by mating 2 clones of $P$. pseudodelicatissima and also 2 clones of $P$. multiseries. Fryxell et al. (1991) noted auxosporulation in a clonal culture of $P$. subcurvata. Roshchin (1990) reported dioecious-monoecious sexual reproduction in Nitzschia lanceolata. Chepurnov \& Mann $(1997,1999)$ observed that dioeciousmonoecious sexual reproduction and vegetative pseudoauxosporulation all appeared in another pennate diatom, Achnanthes longipes. We have observed cell enlargement on 5 occasions in monoclonal cultures 
and on 2 occasions in interclonal cultures, but we were unable to identify putative gametes. Of the 5 monoclonal cultures, one was a clonal reisolate from 9D3C2-1. At this stage, we are unable to conclude whether this phenomenon is due to vegetative or sexual reproduction. Thus, we use the term 'enlargement' instead of 'auxosporulation' to avoid any potential misunderstanding.

The DA content of rapidly growing $\left(\mu=0.63 \mathrm{~d}^{-1}\right)$, enlarged Pseudo-nitzschia sp. cf. pseudodelicatissima cells was usually about an order of magnitude higher than that of the original, slowly growing ( $\mu=0.1$ to $0.2 \mathrm{~d}^{-1}$ ) small cells (Table 1 ), and probably reflected, at least in part, the increased cell size. Similarly, for $P$. multiseries, newly isolated cultures comprised of larger cells usually have a high DA content, yet as the cells become progressively smaller and grow more slowly, toxin production and cellular toxin content decline markedly (Bates et al. 1991, Pan et al. 1996a). For example, in the first toxic $P$. multiseries clone (NPNRC/NPBIO) isolated in 1988 from Cardigan Bay, Canada, the cellular DA content was 5 to $10 \mathrm{pg} \mathrm{cell}^{-1}$ (Bates et al. 1991) when its growth rate was 0.6 to $0.8 \mathrm{~d}^{-1}$. By 1993, toxin levels had declined to $0.5 \mathrm{pg}$ cell ${ }^{-1}$ or less, accompanied by a decrease in maximum growth rate to 0.2 to $0.25 \mathrm{~d}^{-1}$ (Pan et al. 1996a). Recently, Davidovich \& Bates (1998) reestablished the maximal cell size of earlier $P$. multiseries clones through dioecious sexual reproduction, and the resulting large daughter cells exhibited markedly higher toxin cell quotas (Bates et al. 1999). The changes in toxicity as a function of decreased cell size and growth rate in our $P$. sp. cf. pseudodelicatissima clones are consistent with those reported for $P$. multiseries (Pan et al. 1996a,b, Bates et al. 1999).

The clones of Pseudo-nitzschia sp. cf. pseudodelicatissima examined herein appear to have several unique morphological characteristics that distinguish them from cells of previously described P. pseudodelicatissima isolates from the northwest US coast and from New Zealand. One of the typical characteristics of $P$. pseudodelicatissima is the presence of single rows of valve face poroids in each interstria (Hasle et al. 1996), in which the central portion of the velum is unperforated and peripherally surrounded by 5 to 8 hymenated sectors. The cultures isolated from the Louisiana shelf exhibit an atypical velum morphology consisting of 2 to 4 large hymenate sectors (Fig. 6C). This larger, simpler velum structure is similar to that of P. cuspidata (Hasle et al. 1996, C. Villac pers. comm.). Nonetheless, other morphologic traits such as valve width $(<2.5 \mu \mathrm{m})$ indicate that these cultures more closely resemble $P$. pseudodelicatissima. If the large hymenate sectors were interpreted to represent double rows of poroids (as suggested in Fig. 6B), this feature would be indicative of Pseudo-nitzschia delicatissima. The number of poroids in $1 \mu \mathrm{m}$, however, is typical of $P$. pseudodelicatissima (4 to 6 poroids per $1 \mu \mathrm{m}$ ) rather than $P$. delicatissima (10 to 12 poroids per $1 \mu \mathrm{m})$. Thus, while the hymenate structure is atypical, measurements of valve morphology indicate that the morphology of the Louisiana shelf cultures most closely coincides with that of $P$. pseudodelicatissima. It should be noted that a similar, atypical hymenate structure was reported previously by Hasle (1965) for this species (as Nitzschia delicatula, Hasle's Plate 16), further supporting our identification. The atypical hymenate structure has been observed in some field samples as well (Parsons pers. obs.), although it is unclear whether this is due to environmental factors (possibly recreated in the culture studies) or represents natural genetic variability. Interestingly, we have recently observed an unusual cross-reaction of $P$. sp. cf. pseudodelicatissima from the Louisiana shelf with taxon-specific rDNA probes (Parsons et al. 1999). A more detailed investigation describing the complications in morphology and classification outlined above, and including sequencing of the LSU rRNA gene, is underway and will appear in a later paper. These distinctive morphologic and genetic characteristics, coupled with the ability to produce domoic acid and undergo cell enlargement, suggest that the isolates used in this study have many attributes deviating from those of a typical P. pseudodelicatissima cell. In view of these differences, we suggest that the isolates examined herein merit classification as $P$. sp. cf. pseudodelicatissima. Clearly, there appears to be a great deal of variability in the pseudodelicatissima group that requires further study (Parsons et al. 1999).

In summary, we have confirmed DA production by 2 of 7 cultured Pseudo-nitzschia sp. cf. pseudodelicatissima clones isolated from Louisiana shelf waters of the Gulf of Mexico. This is the first reported confirmation using tandem mass spectrometry of DA synthesis by $P$. sp. cf. pseudodelicatissima cultures, and unequivocally establishes $P$. sp. cf. pseudodelicatissima as a source of this toxin in the northern Gulf of Mexico. The present study shows that net DA production is confined to the early exponential phase of $P$. sp. cf. pseudodelicatissima cultures, when primary cell metabolism is most active. The lack of toxin accumulation in the later stages of batch culture growth did not appear related to bacterial degradation of DA. Our findings suggest that the presence of $P$. sp. cf. pseudodelicatissima cells, even at the low levels of early, rapidly growing bloom stages, can potentially lead to toxic events in Louisiana coastal waters.

Acknowledgements. We are most grateful to Dr Greta Fryxell for her assistance with the species identification and valuable 
comments on an early draft of this manuscript. We thank Drs Steve Morton, Fran Van Dolah, and John Ramsdell for their comments on the manuscript. We thank Mr Dave O'Neil (Institute for Marine Biosciences, NRCC, Halifax, Canada) for scanning electron microscopy. This study was supported in part by NSF Grants OCE9633805 to GJD and OCE 9633806 to QD, and by operating funds from NOAA/NOS and LUMCON. The National Ocean Service (NOS) does not approve, recommend, or endorse any product or material mentioned in this publication. No reference shall be made to NOS, or to this publication furnished by NOS, in any advertising or sales promotion which would indicate or imply that NOS approves, recommends, or endorses any product or material mentioned herein or which has as its purpose any intent to cause directly or indirectly the advertised product to be used or purchased because of NOS publication.

\section{LITERATURE CITED}

Adams NG, Lesoing M, Trainer VL (2000) Environmental conditions associated with domoic acid in razor clams on the Washington coast. J Shellfish Res 19:1007-1015

Bates SS (1998) Ecophysiology and metabolism of ASP toxin production. NATO ASI Ser G Ecol Sci 41:405-426

Bates SS, Bird CJ, de Freitas ASW, Foxall R, Gilgan MW, Hanic LA, Johnson GE, McCulloch AW, Odense P, Pocklington R, Quilliam MA, Sim PG, Smith JC, Subba Rao DV, Todd CD, Walter JA, Wright JLC (1989) Pennate diatom Nitzschia pungens as the primary source of domoic acid, a toxin in shellfish from eastern Prince Edward Island, Canada. Can J Fish Aquat Sci 46:1203-1215

Bates SS, de Freitas ASW, Milley JE, Pocklington R, Quilliam MA, Smith JC, Worms J (1991) Controls on domoic acid production by the diatom Nitzschia pungens f. multiseries in culture: nutrients and irradiance. Can J Fish Aquat Sci 48:1136-1144

Bates SS, Garrison DL, Horner RA (1998) Bloom dynamics and physiology of domoic-acid-producing Pseudo-nitzschia species. NATO ASI Ser G Ecol Sci 41:267-292

Bates SS, Hiltz MF, Leger C (1999) Domoic acid toxicity of large new cells of Pseudo-nitzschia multiseries resulting from sexual reproduction. Can Tech Rept Fish Aquat Sci 2261:21-26

Chepurnov VA, Mann DG (1997) Variation in the sexual behaviour of natural clones of Achnanthes longipes (Bacillariophyta). Eur J Phycol 32:147-154

Chepurnov VA, Mann DG (1999) Variation in the sexual behaviour of Achnanthes longipes (Bacillariophyta). II. Inbred monoecious lineages. Eur J Phycol 34:1-11

Cupp EE (1943) Marine diatoms of the west coast of north America. Bull Scripps Inst Oceanogr Univ Calif 5:30-33

Davidovich NA, Bates SS (1998) Sexual reproduction in the pennate diatoms Pseudo-nitzschia multiseries and P. pseudodelicatissima (Bacillariophyceae). J Phycol 34:126-137

Dickey RW, Fryxell GA, Grande HR, Roelke D (1992) Detection of marine toxin okadaic acid and domoic acid in shellfish and phytoplankton in Gulf of Mexico. Toxicon 30: 355-359

Dortch Q, Robichaux R, Pool S, Milsted D, Mire G, Rabalais NN, Soniat TM, Fryxell GA, Turner RE, Parsons ML (1997) Abundance and vertical flux of Pseudo-nitzschia in the northern Gulf of Mexico. Mar Ecol Prog Ser 146:249-264

Doucette GJ, McGovern ER, Babinchak JA (1999) Algicidal bacteria active against Gymnodinium breve (Dinophyceae). I. Bacterial isolation and characterization of killing activity. J Phycol 35:1447-1454
Fryxell GA, Garza SA, Roelke DL (1991) Auxospore formation in an Antarctic clone of Nitzschia subcurvata Hasle. Diatom Res 6:235-245

Garrison DL, Conrad SM, Eiles PP, Waldron EM (1992) Confirmation of domoic acid production by Pseudonitzschia australis (Bacillariophyceae) in culture. J Phycol 28: 604-607

Guillard RL, Ryther JH (1962) Studies of marine planktonic diatoms. I. Cyclotella nana Hustedt, and Detonula confervacea (Cleve) Gran. Can J Microbiol 8:229-239

Hasle GR (1965) Nitzschia and Fragilariopsis species studied in the light and electron microscopes. II. The group Pseudonitzschia. Skr Nor Videns-Akakad, Oslo (Matnaturvidensk Kl) 18:1-45

Hasle GR, Lange CB, Syvertsen EE (1996) A review of Pseudo-nitzschia, with special reference to the Skagerrak, North Atlantic, and adjacent waters. Helgol Meeresunters 50:131-175

Lundholm N, Skov J, Pocklington R, Moestrup Ø (1994) Domoic acid, the toxic amino acid responsible for amnesic shellfish poisoning, now in Pseudonitzschia seriata (Bacillariophyceae) in Europe. Phycologia 33:475-478

Lundholm N, Skov J, Pocklington R, Moestrup Ø (1997) Studies on the marine planktonic diatom Pseudo-nitzschia. 2. Autecology of $P$. pseudodelicatissima based on isolates from Danish waters. Phycologia 36:381-388

Mann DJ, Chepurnov VA, Droop SJM (1999) Sexuality, incompatibility, size variation, and preferential polyandry in natural populations and clones of Sellaphora pupula (Bacillariophyceae). J Phycol 35:152-170

Martin JL, Haya K, Burridge LE, Wildish DJ (1990) Nitzschia pseudodelicatissima - a source of domoic acid in the Bay of Fundy, eastern Canada. Mar Ecol Prog Ser 67:177-182

Pan Y, Subba Rao DV, Mann KH, Brown RG, Pocklington R (1996a) Effect of silicate limitation on production of domoic acid, a neurotoxin, by the diatom Pseudo-nitzschia multiseries. I. Batch culture studies. Mar Ecol Prog Ser 131:225-233

Pan Y, Subba Rao DV, Mann KH (1996b) Changes in domoic acid production and cellular chemical composition of the toxigenic diatom Pseudo-nitzschia multiseries under phosphate limitation. J Phycol 32:371-381

Pan Y, Bates SS, Cembella AD (1998) Environmental stress and domoic acid production by Pseudo-nitzschia: a physiological perspective. Nat Toxins 6:127-136

Parsons ML, Scholin CA, Miller PE, Doucette GJ, Powell CL, Fryxell GA, Dortch Q, Soniat TM (1999) Pseudo-nitzschia species (Bacillariophyceae) in Louisiana coastal waters: molecular probe field trials, genetic variability, and domoic acid analyses. J Phycol 35:1368-1378

Quilliam MA (1996) Liquid chromatography-mass spectrometry of seafood toxins. J Chromat Lib 59:415-444

Reap ME (1991) Nitzschia pungens Grunow f. multiseries Hasle: growth phases and toxicity of clonal culture isolated from Galveston, Texas. MSc thesis, Texas A\&M University, College Station

Rhodes L, Scholin C, Garthwaite I (1998) Pseudo-nitzschia in New Zealand and the role of DNA probes and immunoassays in refining marine biotoxin monitoring programmes. Nat Toxins 6:105-111

Roschin AM (1990) Sochetanie odnodomnosti i dvudomosti u diatomovoj vodorosli Nitzschia lanceolata W. Sm. Zh Obshch Biol 51:699-708 (cited in Chepurnov \& Mann 1997)

Scholin CA and 25 others (2000) Mortality of sea lions along the central California coast linked to a toxic diatom bloom. Nature 403:80-84

Sierra Beltran A, Palafox-Uribe M, Grajales-Montiel J, Cruz- 
Villacorta A, Ochoa JL (1997) Sea bird mortality at Cabo San Lucas, Mexico: evidence that toxic diatom blooms are spreading. Toxicon 35:447-453

Subba Rao DV, Wohlgeschaffen G (1990) Morphological variants of Nitzschia pungens Grunow f. multiseries Hasle. Bot Mar 33:545-550

Subba Rao DV, Quilliam MA, Pocklington R (1988) Domoic acid-a neurotoxic amino acid produced by the marine diatom Nitzschia pungens in culture. Can J Fish Aquat Sci 45:2076-2079

Todd ECD (1993) Domoic acid and amnesic shellfish poisoning - a review. J Food Prot 56:69-83

Editorial responsibility: Otto Kinne (Editor),

Oldendorf/Luhe, Germany van Dolah FM, Leighfield TA, Haynes BL, Hampson DR, Ramsdell JS (1997) A microplate receptor assay for the amnesic shellfish poisoning toxin, domoic acid, utilizing a cloned glutamate receptor. Anal Biochem 245:102-105

Work TM, Barr B, Beale AM, Fritz L, Quilliam MA, Wright JLC (1993) Epidemiology of domoic acid poisoning in brown pelicans (Pelicanus occidentalis) and Brandt's cormorants (Phalacrocorax penicillatus) in California. J Zoo Wildl Med 24:54-62

Zwietering MH, Jongenburger I, Rombouts FM, van't Riet K (1990) Modeling of the bacterial growth curve. Appl Environ Microbiol 56:1875-1881

Submitted: March 27, 2000; Accepted: February 7, 2001

Proofs received from author(s): September 12, 2001 